\title{
Impact of tangible book value and operating earnings on firm value variants in South Africa
}

\begin{tabular}{|c|c|}
\hline $\begin{array}{l}\text { Authors: } \\
\text { Atanas Sixpen } \\
\text { Olufemi P. Ade } \\
\text { Rajendra Raja }\end{array}$ & $\begin{array}{l}\mathrm{e}^{1,2} \\
\text { yeye }^{3} \\
\mathrm{am}^{4}\end{array}$ \\
\hline $\begin{array}{l}\text { Affiliations: } \\
{ }^{1} \text { Department } \\
\text { School of Accc } \\
\text { Economics an } \\
\text { University of } \\
\text { Durban, South }\end{array}$ & $\begin{array}{l}\text { f Finance, } \\
\text { unting, } \\
\text { Finance, } \\
\text { waZulu-Natal, } \\
\text { Africa }\end{array}$ \\
\hline $\begin{array}{l}{ }^{2} \text { Department } \\
\text { National Univ } \\
\text { Science and Te } \\
\text { Bulawayo, Zim }\end{array}$ & $\begin{array}{l}\text { f Finance, } \\
\text { rsity of } \\
\text { chnology, } \\
\text { babwe }\end{array}$ \\
\hline $\begin{array}{l}{ }^{3} \text { Department } \\
\text { and Finance, } \\
\text { Management } \\
\text { Federal Unive } \\
\text { Oye-Ekiti, Nige }\end{array}$ & $\begin{array}{l}\text { f Banking } \\
\text { aculty of } \\
\text { ciences, } \\
\text { sity, } \\
\text { ria }\end{array}$ \\
\hline $\begin{array}{l}{ }^{4} \text { Department } \\
\text { Accounting an } \\
\text { Management, } \\
\text { Accounting, Ec } \\
\text { and Finance, } \\
\text { of KwaZulu-Na } \\
\text { South Africa }\end{array}$ & $\begin{array}{l}\text { f Managerial } \\
\text { d Financial } \\
\text { School of } \\
\text { onomics } \\
\text { niversity } \\
\text { tal, Durban, }\end{array}$ \\
\hline $\begin{array}{l}\text { Correspondin } \\
\text { Atanas Sixpen } \\
\text { agsixpence@g }\end{array}$ & $\begin{array}{l}\text { author: } \\
\text { mail.com }\end{array}$ \\
\hline $\begin{array}{l}\text { Dates: } \\
\text { Received: } 21 \\
\text { Accepted: } 12 \\
\text { Published: } 29\end{array}$ & $\begin{array}{l}\text { pr. } 2020 \\
\text { lov. } 2020 \\
\text { an. } 2021\end{array}$ \\
\hline $\begin{array}{l}\text { How to cite th } \\
\text { Sixpence, A., } \\
\text { \& Rajaram, R., } \\
\text { of tangible bo } \\
\text { operating earr } \\
\text { value variants } \\
\text { Africa', Journa } \\
\text { and Financial } \\
\text { 14(1), a575. h } \\
\text { org/10.4102/j }\end{array}$ & $\begin{array}{l}\text { is article: } \\
\text { deyeye, O.P. } \\
2021 \text {, 'Impact } \\
\text { k value and } \\
\text { ings on firm } \\
\text { in South } \\
\text { of Economic } \\
\text { ciences } \\
\text { tps://doi. } \\
\text { f.v14i1.575 }\end{array}$ \\
\hline Read online: & \\
\hline 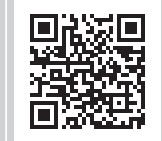 & $\begin{array}{l}\text { Scan this QR } \\
\text { code with your } \\
\text { smart phone or } \\
\text { mobile device } \\
\text { to read online. }\end{array}$ \\
\hline
\end{tabular}

Orientation: Empirical knowledge regarding which financial statement variables are linked to firm value is critical for profitable equity investment.

Research purpose: The study examines the impact of earnings before interest and taxes from continuing operations (EBITCOs) and tangible book value (TBV) on firm value variants (enterprise value and market capitalisation) in South Africa.

Motivation for the study: The need to determine the impact of book value and operating income on firm value post-global financial crisis motivated this study. Furthermore, conflicting empirical results motivated this investigation to determine if value relevance depends on the measure of firm value used by employing two variants of firm value.

Research approach/design and method: A dynamic panel of 50 firms was used, employing an autoregressive distributed lag model in two-step system generalised method of moments (GMM).

Main findings: Results showed that EBITCO is value relevant regardless of the firm value variant used. Tangible book value lacks value relevance irrespective of the firm value measure used.

Practical/managerial implications: During a takeover bid, investors should use EBITCO in valuing target firms and disregard TBV. New owners in an acquisition are guaranteed value for their money because of the link between EBITCO and enterprise value. Accounting standards setters should maintain the requirement that mandates companies to produce comprehensive financial statements. Company executives should implement strategies that boost EBITCO as a way of maximising shareholder value.

Contribution/value-add: Conservative measures of variables were adopted, something rarely done by scholars. Thus, the study contributes to the scant body of knowledge on value relevance that utilises conservative financial statement variable measures.

Keywords: tangible book value; earnings from continuing operations; enterprise value; market capitalisation; system GMM; South Africa.

\section{Introduction}

The value of a firm to an equity investor is contingent upon the amount of information regarding operating performance of that particular firm that the investor is able to get. For most investors, financial statements are key sources of firm performance information. This study examines the impact of tangible book value (TBV) and earnings before interest and taxes from continuing operations (EBITCOs) on firm value variants on the Johannesburg Stock Exchange (JSE) following the aftershocks of the 2007 to 2009 global financial crisis (GFC). According to the FTSE Russell JSE Factsheet of 31 January 2018, the JSE All-share Index had a return of $-23.20 \%$ in 2008 . On the other hand, financial statement variables such as TBV and EBITCO had positive growth for most firms in the JSE All-share Index. Whilst the discord between share prices and financial statement variables may be understood because of the negative sentiment associated with the GFC, the trend continued after the crisis period. In the year 2011, the All-share Index had a return of a mere $2.6 \%$ and in the year 2016, it recorded another 2.6\% return (FTSE Russell JSE Factsheet). In both years, TBV and EBITCO recorded good positive growth for the majority of firms in the All-share Index. During the other years between 2010 and 2017, the performance of the All-share Index and firm performance are not in tandem. This shows a detachment between the source of firm performance information (financial statements) and the outcome variable (share prices or firm value). This detachment is a cause for concern because investors rely on financial statements 
to forecast share prices whilst making equity investment decisions. Ideally, a positive relationship between firm performance indicators and equity prices or firm value is expected (Beisland 2009), which is not the case during the period under study. The problem is that share prices are falling (and stock market investors are incurring losses on their investments) but firms would have reported a profit in their financial statements, which raises questions regarding the usefulness of financial statement variables in explaining firm value: Are the losses incurred by investors a result of markets being over or undervalued, or is it because information in financial statements is no longer relevant in explaining firm value? This research endeavours to answer these questions, motivated by the discord in research findings by various scholars as shown in the literature review section.

Two different versions of firm value are examined, namely enterprise value and market capitalisation. These are the response variables, with TBV and EBITCO deployed as explanatory variables. Results from these two versions of firm value are compared. Enterprise value is mostly used in measuring firm value for takeover purposes, that is a company's purchase price. There is a dearth of literature focussing on information content of enterprise value, so this research makes a novel contribution in this field of study. Market capitalisation represents the consensus value of what the many equity market players deem the firm is worth, given by the product of share prices and total shares in issue. Enterprise value is considered to be better than market capitalisation because it includes important variables such as debt and cash, which are not considered in market capitalisation. The study focusses on TBV because it summarises a firm's overall tangible asset base net of all liabilities, a measure of assets attributable to shareholders. The focus on TBV is a departure from what a myriad of scholars focusses on, making this study a novel one. Earnings before interest and taxes from continuing operations are included because these show a firm's operating earnings emanating from ongoing activities, which is a key determinant of its going concern status moving forward. Furthermore, we also base our justification for using these variables on a conceptual framework given by Ohlson (1995).

The article begins with a review of related studies and identifies a knowledge gap. Materials and methods used in the study are provided thereafter. After that results are presented and analysed. A discussion of findings and conclusions completes the article.

\section{Related literature}

Value relevance of EBIT (amongst other variables) is the subject of a study by Davern et al. (2019). The study sought to determine whether or not investors still use year-end financial statements in equity valuation in Australia. A mixed-methods approach was used, where interviews revealed that investors still use year-end financial statements. Regression results affirmed the narrative from interviews, with EBIT being one of the value relevant variables. However, Lev and Gu (2016) questioned the informativeness of financial statements in explaining share price movements considering the availability of other information highways in the digital era. In Malaysia, Mirza, Malik and Abdul-Hamid (2018) concluded that book value (BV) has value relevance whilst earnings do not have any usefulness in explaining share prices. This conforms with conclusions by Zulu, De Klerk and Oberholster (2017) who studied usefulness of interim financial statements by using a data set of JSE-listed firms.

Specifically, the study showed that BV affects market value of equity whilst earnings did not show any significant effect on equity prices. On the contrary, evidence from the same market (JSE) provided by Sixpence and Adeyeye (2019) shows that operating income has value relevance, whilst BV is not relevant, based on a dynamic panel of JSE-listed firms. However, these two studies used different variables; Zulu et al. (2017) used market capitalisation as the response variable, whilst Sixpence and Adeyeye (2019) used share prices. Furthermore, the earnings measure used is different; whilst Sixpence and Adeyeye (2019) used operating income, Zulu et al. (2017) used net profit after tax. This may help explain the differences in findings.

Der, Polak and Masri (2016) used a number of simple linear regressions and multivariate regressions adapted from the Ohlson model to analyse the usefulness of BV, cash flows and earnings in Singapore. Based on pooled regression, the study revealed that BV's usefulness surpasses that of earnings, with cash flows exhibiting a very weak association with equity prices. The impact of financial variables on market capitalisation was also investigated by Pavone (2019), by using a data set of Italian companies for the period 2008 to 2017. The financial variables studied include return on equity, earnings yield and operating deflated by turnover per share. Whilst correlation analysis shows some (weak) association between market capitalisation and financial variables, regression analysis proved that not even one of the six explanatory variables are significant at $5 \%$ level, meaning they are not value relevant. Although market capitalisation is also one of the two firm value measures in this study, our study is distinctive because of the marked difference between our explanatory variables (TBV and EBITCO) and those in Pavone (2019). Furthermore, we use autoregressive distributed lag models, whilst Pavone (2019) used static models.

A modified Ohlson model was used by Omokhudu and Ibadin (2015) to study the usefulness of financial statement data in Nigeria. Whilst BV is not significant in that study, earnings are amongst other variables found to be useful in explicating firm value. However, another study on the Nigerian stock market by Olugbenga and Atanda (2014) produced slightly different results. Further to earnings, cash flows and dividends being relevant, BV was also relevant. The Ohlson model was again used in Khanna (2014), which focusses on Indian firms. Empirical evidence to the 
effect that earnings per share (EPS) and book value per share (BVPS) possess value relevance was provided. Per-share-based metrics were also employed by Pervan and Bartulovic (2014) in a study of five European stock markets. These studies invariably employ static models. Our present study employs dynamic models, which is a departure from the majority of studies in extant literature (justification is provided in the section 'Models and data issues').

Dahmash and Qabajeh (2012) analysed the effect of abnormal earnings and BV on market capitalisation in Jordan. Pooled regression results revealed value relevance of both variables. Just like the majority of other studies, the models used are based on Ohlson (1995). Market capitalisation is one of the two response variables used in this study but the explanatory variables are technically different. Glezakos, Mylonakis and Kafouros (2012) analysed the impact of EPS and BVPS on share prices by using 38 randomly selected Athens Stock Exchange-listed firms. Ohlson-type static models were used, excluding 'other information'. Based on an analysis of coefficients of determination, the explanatory power of both BVPS and EPS was found to have increased over time. However, the explanatory power of BVPS was more than that of EPS. Whilst Glezakos et al. (2012) used earnings and book values on a per-share basis, our current study does not use sharedeflated variables, but, rather, it employs log transformation of data, as justified in the section 'Models and data issues'. Few researchers used log-transformed data (Clout \& Willett 2016).

\section{Knowledge gap}

This review has demonstrated that value relevance studies have largely been confined to the developed capital markets. Over the years, however, researchers are increasingly focussing on the developing world, for example Khanna (2014), India; Omokhudu and Ibadin (2015), Nigeria; Nyabundi (2013), Kenya; Hai, Diem and Binh (2015), Vietnam; Mirza et al. (2018), Malaysia; Chandrapala (2013), Sri Lanka; Zulu et al. (2017), South Africa; and Sixpence, Adeyeye and Rajaram (2020), Zimbabwe. Nevertheless, there is still scant literature, which focusses on Southern Africa. Not much value relevance research has been carried out that focusses on South Africa, Africa's biggest equities exchange by market capitalisation. A knowledge gap thus exists, and this research intends to help plug that gap.

Many value relevance researchers prefer using share prices over market capitalisation as the response variable in value relevance research as shown by literature reviewed above. In cases where market capitalisation is used, the focus is not on book values and earnings as explanatory variables. Instead, explanatory variables like return on assets and return on equity are used (Pavone 2019). There is also a dearth of value relevance literature where enterprise value is the dependent variable. This research aims to fill this gap. Market capitalisation and enterprise value are important indicators of firm value to equity investors, hence our focus on them.
With regard to methodology, extant literature shows that studies on value relevance have largely employed static models (Baltariu 2015; Beisland 2009). There is a need to explore dynamic models in value relevance research. Dynamic models enable us to have consistent estimates of variables under study (Bond 2002). This is a desirable trait that helps in making sure that credible results are found. It is also noteworthy that equity prices are dynamic in nature; thus, using a dynamic model is appropriate in this case. There is a methodological gap in this area of study that this research aims to fill. Furthermore, the studies predominantly use ordinary least squares (OLS) estimators and this study employs System GMM estimators, which are more robust than OLS estimators (Roodman 2009).

\section{Hypotheses}

Following the literature reviewed above, the study tests these hypotheses:

H1: A relationship exists between firm value (market capitalisation and enterprise value) and TBV.

H2: An association exists between firm value (market capitalisation and enterprise value) and EBITCO.

\section{Materials and methods}

This section presents and justifies research methods employed in this investigation.

\section{Population and sampling issues}

The study's population comprises all JSE-listed companies that were active for the entire time span from 01 January 2010 to 31 December 2017, excluding financial companies. There were 377 JSE-listed companies as at the end of 2017 according to the African Securities Exchanges Association 2017 Annual Report.

Excluding new listings during the period and financials gives a total population size of 182 companies. To cater for measurement and classification error, the population size is rounded up to 200 companies. The decision to leave out financial companies is premised on the fact that financials' operations are different from non-financials, as well as the unique nature of their assets and liabilities. This approach is also in accordance with many other researchers documented in Baltariu (2015).

As at 31 December 2017, the JSE was made up of 10 industry classifications, which are based on the FTSE Russell Industry Classification Benchmark. At an industry level, the population comprises nine industries, and these are proportionately represented in the sample to enhance sample quality. Cluster sampling is used, where each industry is a cluster. Firms were drawn from each cluster using purposive sampling. Purposive sampling is employed to ensure inclusion of both high and low capitalised firms so as to avoid scale bias. The size of the sample is based on 
an enhancement of a rule of thumb, which says if the population of study exceeds 100 individuals, a sample size of between 5 and $10 \%$ is deemed representative of the population. This study enhances this rule of thumb by sampling $25 \%$ of the population, which yields 50 companies. The distribution of the study sample across sectors is shown in Table 1.

\section{Models and data issues}

The study uses models adapted from the Ohlson model. Modification of the Ohlson model entails logging all variables, including the first lag of the response variable as an explanatory variable and lagging each explanatory variable (autoregressive distributed lag model) in line with Alexander, Falta and Willett (2012) and Clout and Willett (2016). Alexander et al. (2012) showed that when examining links between market values and financial statement variables, models are likely to be better specified when all variables are logged and an autoregressive distributed lag model is used. This study adopts this approach in all models. The levels models used are as follows:

$\begin{aligned} \ln F v_{i t}= & \beta_{0}+\varphi \ln F V_{i t-1}+\beta_{1} \ln B V_{i t}+\beta_{2} \ln B V_{i t-1}+\beta_{1} \ln E B I T_{i t}+ \\ & \beta_{4} \ln E B I T_{i t-1+} \varepsilon_{i t}\end{aligned}$

$\ln F v_{i t}=\beta_{0}+\varphi \ln F V_{i t-1}+\beta_{1} \ln B V_{i t}+\beta_{2} \ln B V_{i t-1}+\varepsilon_{i t}$

[Eqn 2]

$\ln F v_{i t}=\beta_{0}+\varphi \ln F V_{i t-1}+\beta_{1} \ln E B I T_{i t}+\beta_{2} \ln E B I T_{i t-1+} \varepsilon_{i t} \quad$ [Eqn 3]

where:

$\ln F v_{i t}$ and $\ln F v_{i t-1}=$ natural log of current company value and its first lag for company $i$, respectively.

$\ln B V_{i t}$ and $\ln B V_{i t-1}=$ natural log of a company's current book value and its first lag, respectively.

$\ln E B I T_{i t}$ and $\ln E B I T_{i t-1}=$ natural log of a company's operating income before interest and taxes from continuing operations in time $\boldsymbol{t}$ and $\boldsymbol{t} \mathbf{- 1}$, respectively.

$\varepsilon_{i t}=$ disturbance term for company $i$ in time $t$.

TABLE 1: Distribution of study sample firms across sectors.

\begin{tabular}{lc}
\hline Industry sector & Firms sampled \\
\hline Energy (oil and gas) & 1 \\
Basic materials & 13 \\
Health care & 2 \\
Industrials & 14 \\
Technology & 4 \\
Consumer services & 9 \\
Consumer goods & 5 \\
Telecommunications & 2 \\
Utilities & 0 \\
\hline Total & $\mathbf{5 0}$ \\
\hline
\end{tabular}

Equations 2 and 3 are nested in Equation 1, and they are used both to check individual variables' value relevance (simple linear regression setting) and being a robustness check for dropping a correlated variable.

We use share prices recorded on the first day of the fourth month after financial year end. This circumvents 'look-ahead bias' highlighted by Banz and Breen (1986). Share prices were obtained from Yahoo Finance, whilst accounting variables were calculated or taken from financial statements. Financial statements were obtained from the individual firms' websites. Variables are defined or calculated as shown in Table 2.

\section{Econometric issues}

Using $x$ tabond 2 command in Stata, we assume that:

- Errors are correlated within individuals and no such correlation exists across individuals. Inclusion of time dummies enhances this assumption (Roodman 2009). Resultantly, we incorporate time dummies in all models.

- First lag of response variables is endogenous in the model, so it is instrumented GMM-style.

- The explanatory variables are exogenous, implying that they have to be entered IV-style. Over and above the model variables, net asset value and debt to equity ratio are included as additional IV-style instruments to boost model efficiency.

- Response variables follow a random walk because share prices are embedded in both of them. In such a scenario, Difference GMM does not perform well compared with System GMM (Blundell \& Bond 1998). Consequently, the study uses System GMM.

Implementation of the models is based on forward orthogonal differences instead of first difference transformation. The first difference transformation enlarges gaps in unbalanced panels. As log transformations of negative figures (EBITCO and TBV) creates gaps, orthogonal deviations help in maximising sample size.

\section{Results}

Various aspects of the results from this investigation are presented in this section.

\section{Descriptive statistics}

Descriptive statistics on raw data with respect to variables used are presented in Table 3. The statistics chosen are the

TABLE 2: Variable calculation.

\begin{tabular}{ll}
\hline Variable name & Calculation \\
\hline EBIT = EBITCO & $\begin{array}{l}\text { Operating income (less income from discontinued } \\
\text { operations, if any) }\end{array}$ \\
Tangible book value & $\begin{array}{l}\text { Total assets }- \text { intangible assets (like goodwill) }- \text { total } \\
\text { liabilities }\end{array}$ \\
Enterprise value & $\begin{array}{l}\text { (Share price } \times \text { issued shares) }+ \text { preferred stock + minority } \\
\text { interest + total debt }- \text { cash and cash equivalents }\end{array}$ \\
Market capitalisation & Share price $\times$ issued shares \\
\hline
\end{tabular}

EBITCO, earnings before interest and taxes from continuing operations. 
number of observations, total, average, standard deviation and the maximum and minimum values. Enterprise value and market capitalisation are the response variables. Explanatory variables are TBV and EBITCO whilst net asset value and debt to equity ratio are additional instrumental variables.

The sample comprises both large and small companies (by market capitalisation) as shown by the standard deviation and the difference between minimum and maximum values on the variable market capitalisation. This is a deliberate strategy to ensure that there is no bias towards either big or small companies.

The variable enterprise value also depicts the wide diversity of the research sample, which enhances sample quality.

The standard deviation, read together with minimum and maximum values, depicts variation that is expected to occur considering that both small and large companies form the study sample. The statistic 'minimum' on the variable EBITCO shows that there are some years where firms reported operating losses, but these are not too many because the average is a large positive figure, about half of the largest observation on EBITCO. There are also some struggling firms as shown by negative TBV. However, considering the small gap between the average and maximum values, there are very few firm-year combinations with negative TBV. The implication of negative EBITCO and TBV is that some observations will be lost when these variables are converted into their natural logarithms, but these are very few. The next section assesses the correlations between the variables.

\section{Correlation analysis}

Table 4 presents correlation coefficients between the variables.

An asterisk next to a correlation coefficient depicts statistical significance ( $5 \%$ significance level was used). Beneath each correlation coefficient are the respective $p$-values.

A positive association exists between enterprise value (EV) and EBITCO (0.6562), which is statistically significant. Furthermore, a significant association exists between EV and TBV (0.6090). Earnings before interest and taxes from continuing operations and TBV have a high, significant and positive correlation, but the correlation coefficient is below
0.8 , implying very low chances of collinearity between the variables.

Similarly, a positive and significant association exists between market capitalisation and EBITCO (0.8430) and TBV (0.8971). This shows a much stronger relationship between market capitalisation and the explanatory variables than what was observed between EV and the same explanatory variables. The correlation coefficient between the variables EV and market capitalisation is of no consequence because these are response variables used in various models; they are not used together in the same model.

\section{Regression results}

Two measures of firm value are used and the section 'Relationship between enterprise value and tangible book value and earnings before interest and taxes from continuing operation' uses EV to measure firm value (Scenario 1) whilst the section 'Relationship between market capitalisation and tangible book value and earnings before interest and taxes from continuing operations' presents results where market capitalisation (MC) represents firm value (Scenario 2). Statistical package Stata, version 12, was used to run the regressions.

\section{Relationship between enterprise value and tangible book value and earnings before interest and taxes from continuing operation}

Regression results for Scenario 1, where EV is the response variable, are given in Table 5. To check robustness of model results and also measure value relevance of one variable without controlling for the other variable, one explanatory variable at a time is left out of the model. Furthermore, the lag structure is also changed to check sensitivity of model results to lag limit changes as suggested by Roodman (2009).

TABLE 4: Correlation matrix.

\begin{tabular}{lcccc}
\hline & Market cap & Enterprise value & EBITCO & Book value \\
\hline Market cap & 1 & - & - & - \\
Enterprise value & $0.6612^{*}$ & 1 & - & - \\
& 0.0000 & - & - & - \\
EBITCO & $0.8430^{*}$ & $0.6562^{*}$ & 1 & - \\
& 0.0000 & 0.0000 & - & - \\
Book value (TBV) & $0.8971^{*}$ & $0.6090^{*}$ & $0.7862^{*}$ & 1 \\
& 0.0000 & 0.0000 & 0.0000 & - \\
\hline
\end{tabular}

TBV, tangible book value; EBITCO, earnings before interest and taxes from continuing operations.

* , $5 \%$ significance level.

TABLE 3: Descriptive statistics.

\begin{tabular}{|c|c|c|c|c|c|c|}
\hline Variables & No. & Total & Average & Deviation & Minimum & Maximum \\
\hline Market capitalisation & 400 & $1.175 e+13$ & $2.938 \mathrm{e}+10$ & $6.000 e+10$ & $1.890 e+07$ & $4.083 e+11$ \\
\hline TBV & 400 & $4.095 e+12$ & $1.024 \mathrm{e}+10$ & $2.613 e+10$ & $-2.280 e+10$ & $2.149 e+11$ \\
\hline EBITCO & 400 & $9.849 e+11$ & $2.462 \mathrm{e}+09$ & $7.218 \mathrm{e}+09$ & $-1.045 e+10$ & $4.965 e+10$ \\
\hline Debt to equity ratio & 400 & 329.3 & 0.823 & 0.870 & 0.0500 & 4.145 \\
\hline Enterprise value & 400 & $1.262 \mathrm{e}+13$ & $3.154 \mathrm{e}+10$ & $6.415 e+10$ & $1.220 \mathrm{e}+07$ & $4.179 e+11$ \\
\hline Net asset value & 400 & $7.127 e+12$ & $1.782 \mathrm{e}+10$ & $4.021 e+10$ & $-5.287 e+10$ & $3.005 e+11$ \\
\hline Firm count & 50 & 50 & 50 & 50 & 50 & 50 \\
\hline
\end{tabular}

TBV, tangible book value; EBITCO, earnings before interest and taxes from continuing operations. 
TABLE 5: Regression results (Log EV as response variable).

\begin{tabular}{|c|c|c|c|c|c|c|c|c|c|c|c|c|}
\hline \multirow[t]{2}{*}{ Variables } & \multicolumn{2}{|c|}{ Model 1} & \multicolumn{2}{|c|}{ Model 2} & \multicolumn{2}{|c|}{ Model 3} & \multicolumn{2}{|c|}{ Model 4} & \multicolumn{2}{|c|}{ Model 5} & \multicolumn{2}{|c|}{ Model 6} \\
\hline & Lag (1 3) & Log EV & Lag (1 3) & Log EV & Lag (1 3) & Log EV & Lag (1 2) & Log EV & Lag (1 2) & Log EV & Lag (1 2) & Log EV \\
\hline Log of Lag EV & $0.901 * * *$ & 0.098 & $0.988 * * *$ & 0.061 & $0.953 * * *$ & 0.049 & $0.914 * * *$ & 0.100 & $1.003^{* * *}$ & 0.056 & $0.947 * * *$ & 0.054 \\
\hline Log EBITCO & $0.151 * *$ & 0.056 & $0.145 * * *$ & 0.050 & - & - & $0.146 * *$ & 0.064 & $0.165^{* *}$ & 0.064 & - & - \\
\hline Log of Lag EBITCO & -0.067 & 0.074 & $-0.124 *$ & 0.069 & - & - & -0.076 & 0.099 & $-0.160 *$ & 0.083 & - & - \\
\hline Log TBV & $0.404 *$ & 0.215 & - & - & $0.434 *$ & 0.236 & 0.402 & 0.257 & - & - & $0.450 *$ & 0.250 \\
\hline Log of Lag TBV & $-0.382 * *$ & 0.178 & - & - & $-0.395^{*}$ & 0.204 & $-0.381^{*}$ & 0.208 & - & - & $-0.405^{*}$ & 0.213 \\
\hline Constant & 0.044 & 0.309 & -0.129 & 0.306 & 0.117 & 0.257 & 0.018 & 0.348 & -0.151 & 0.302 & 0.129 & 0.288 \\
\hline Instrument count & 36 & - & 34 & - & 34 & - & 32 & - & 30 & - & 30 & - \\
\hline Observations & 309 & - & 318 & - & 341 & - & 309 & - & 318 & - & 341 & - \\
\hline Firm count & 48 & - & 49 & - & 49 & - & 48 & - & 49 & - & 49 & - \\
\hline AB-test for AR (1) & -3.69 & - & -3.77 & - & -3.69 & - & -3.72 & - & -3.82 & - & -3.68 & - \\
\hline Probability for AR (1) & 0.000 & - & 0.000 & - & 0.000 & - & 0.000 & - & 0.000 & - & 0.000 & - \\
\hline AB-test for AR (2) & 1.07 & - & 1.17 & - & 0.21 & - & 1.10 & - & 1.24 & - & 0.22 & - \\
\hline Probability for AR (2) & 0.282 & - & 0.242 & - & 0.834 & - & 0.272 & - & 0.213 & - & 0.829 & - \\
\hline Probability for $\mathrm{H}$-test & 0.179 & - & 0.225 & - & 0.342 & - & 0.112 & - & 0.162 & - & 0.169 & - \\
\hline
\end{tabular}

Note: Windmeijer-corrected standard errors are given in brackets. Firm count varies across models because firms with six or more negative values for tangible book value or earnings before interest and taxes from continuing operations are dropped automatically by the software for having too few observations.

AB-test, Arellano-Bond test; $\mathrm{H}$-test, Hansen test; EV, enterprise value; TBV, tangible book value; EBITCO, earnings before interest and taxes from continuing operations; AR(k), autocorrelation of order $\mathrm{k}$. ***, $1 \%$ significance; $* *, 5 \%$ significance; *, $10 \%$ significance.

This gives rise to six models, where Model 1 is the base model. Model 4 is similar to Model 1, the only difference being the lag structure. Model 1 results are thus directly compared with Model 4 results for purposes of checking sensitivity to lag changes. Comparisons are also made to Models 2 and 3 to check the effect of dropping a correlated variable.

Findings for Models 1 and 4: The probability of $F$ indicates that the two models have statistical significance at $1 \%$ level, meaning all explanatory variables combine to explain EV's movements. Whilst Model 1 uses 36 instruments, Model 4 uses 32 instruments. Both cases have the number of observations (309) and groups (48) exceeding the instrument count, implying that there is no problem of too many instruments.

Model 1 depicts a positive association between EV and EBITCO, and this relationship is significant. This means that as EBITCO increases, firm value as measured by EV also increases. The association is significant at $5 \%$ level. When the lag structure is changed in Model 4, the association is still positive and statistically significant ( $5 \%$ level). The coefficient of EBITCO marginally moves from 0.151 in Model 1 to 0.146 in Model 4. Windmeijer-corrected standard errors are small in both cases, changing from 0.056 to 0.064 . The small changes in the coefficients show that the results are robust to lag structure changes. Statistical significance means that EBITCO is useful in explaining the changes recorded by firm value (EV) on the JSE.

Tangible book value is positively related with EV, where the coefficient is 0.404 (Model 1), which moves to 0.402 in response to changes in the lag structure in Model 4. Corrected standard errors are small relative to the coefficients and the errors exhibit minor movement as a result of variation in the lag structure. However, the relationship between EV and
TBV is not statistically significant at $5 \%$ level. This means that TBV is devoid of value relevance when EV is used to measure firm value on the JSE. Tangible book value does not influence a firm's purchase price.

Findings for Models 2 and 5: The variable TBV and its first lag were omitted from the base model, thus producing Models 2 and 5. The resultant models have the same variables, but they use different lag limits. In both cases, the explanatory variables mutually explicate the movement in firm value as shown by the probability of $F$. Standard and GMM instruments in Model 2 total 34. On the other hand, Model 5 uses 30 such instruments. In both cases, there are 318 observations and 49 groups, much larger than the instrument count.

Dropping TBV from the base model causes the coefficient of EBITCO to move from 0.151 in Model 1 to 0.145 in Model 2. Corrected standard errors only move from 0.056 to 0.050 when TBV is dropped. A positive and significant association (1\% level) still exists between EV and EBITCO. In relation to Models 2 and 5, varying the lag length causes the coefficient of EBITCO to change from 0.145 to 0.165 whilst the errors change from 0.050 to 0.064 . All this testifies that the findings are robust to lag structure changes as well as to dropping a variable.

Findings from Models 3 and 6: Earnings before interest and taxes from continuing operations and their first lag were also omitted from the base model, and this gave rise to Models 3 and 6 .

Both models possess $1 \%$ level of significance as shown by the probability of $F$ in the two models. This indicates that the explanatory variables used in the models help in explaining the variation in EV. Model 3 uses a total of 34 standard and GMM instruments whilst Model 6 uses 
30 such instruments. The two models have 341 observations and 49 companies, which is higher than the instrument count, implying that the problem of instrument proliferation does not exist.

Recorded changes in the coefficients of EBITCO resulting from dropping a variable are quite small, and they are within a range that would be expected to occur. The relationship between EV and TBV is still positive, suggesting that increases in TBV lead to an increase in firm value. However, at 5\% level, the relationship lacks significance. Altering the lag limit in Model 6 induces the coefficient of TBV and the corrected errors to register minor movements. These minor movements attest to the fact that the model is robust and its results are reliable. The following section discusses diagnostic test results for all the six models.

Model diagnostics: Autocorrelation test results are displayed at the basement of Table 4 . In all the six models, we reject the hypothesis that there is no serial correlation of order 1 (AR [1]) by using the Arellano-Bond test for serial correlation because the $p$-values of AR (1) are all under 5\%. Roodman (2009) shows that this is expected to occur (because of the lagged response variable) and it is inconsequential. What matters is serial correlation of order two (AR [2]). Based on the Arellano-Bond test, the absence of serial correlation of order 2 is not rejected because all the $p$-values of AR (2) are above $5 \%$. We thus conclude that all the models do not suffer from serial correlation.

The Hansen test is used to test the validity of over-identifying restrictions, where the probability should be greater than 5\% for us to reject the null hypothesis. In all the six models, the null hypothesis is rejected.

We thus conclude that the model restrictions are appropriate. This validates the instruments used.
The next section presents regression results for Scenario 2 where $\mathrm{MC}$ is used as a response variable, maintaining everything else used in Scenario 1 (the explanatory variables and the instruments used). Results from the two scenarios are compared thereafter.

\section{Relationship between market capitalisation and tangible book value and earnings before interest and taxes from continuing operations}

Scenario 2 results are given in Table 6 .

Findings for Models 7 and 10: Just like with the first scenario, these two models are similar in all aspects except the lag limits used. Model 7 is the base model, and Model 10 is used to check sensitivity of the base model to variations in lag limits.

Explanatory variables in Models 7 and 10 mutually explicate the movement in MC at $1 \%$ significance level as shown by the F-test. The total standard and GMM instruments for Model 7 are 36, whilst those for Model 10 are 32. Both models have a total of 309 observations and 48 groups, which is much higher than the instrument count. This is necessary to avoid the problem of too many instruments.

Earnings before interest and taxes from continuing operations exhibit a positive relationship with $\mathrm{MC}$ in both models. As a firm's EBITCO increases, MC increases as investors see value in the firm in question. The relationship is significant at $1 \%$ level.

Although the lag structure has been altered in Model 10, the relationship's level of significance still remains at $1 \%$. The coefficient of EBITCO in Model 7 is 0.207 , and it marginally changes to 0.209 in Model 10.

Model 7's standard errors are 0.045 , moving to 0.055 as a result of variation in the lag structure in Model 10.

TABLE 6: Regression results (Log MC as response variable).

\begin{tabular}{|c|c|c|c|c|c|c|c|c|c|c|c|c|}
\hline \multirow[t]{2}{*}{ Variables } & \multicolumn{2}{|c|}{ Model 7} & \multicolumn{2}{|c|}{ Model 8} & \multicolumn{2}{|c|}{ Model 9} & \multicolumn{2}{|c|}{ Model 10} & \multicolumn{2}{|c|}{ Model 11} & \multicolumn{2}{|c|}{ Model 12} \\
\hline & Lag (1 3) & $\log M C$ & Lag (1 3) & $\log M C$ & Lag (1 3) & Log MC & Lag (1 2) & $\log M C$ & Lag (1 2) & $\log M C$ & Lag (1 2) & Log MC \\
\hline Log of Lag MC & $0.976 * * *$ & 0.043 & $0.996 * * *$ & 0.033 & $0.996 * * *$ & 0.022 & $0.973 * * *$ & 0.045 & $1.005^{* * *}$ & 0.029 & $0.994 * * *$ & 0.025 \\
\hline Log EBITCO & $0.207 * * *$ & 0.045 & $0.199 * * *$ & 0.040 & - & - & $0.209 * * *$ & 0.055 & $0.200 * * *$ & 0.055 & - & - \\
\hline Log of Lag EBITCO & $-0.161 * *$ & 0.064 & $-0.194 * * *$ & 0.048 & - & - & $-0.161 * *$ & 0.079 & $-0.205 * * *$ & 0.066 & - & - \\
\hline Log TBV & 0.144 & 0.099 & - & - & $0.206^{*}$ & 0.122 & 0.146 & 0.100 & - & - & 0.234 & 0.140 \\
\hline Log of Lag TBV & $-0.172 *$ & 0.096 & - & - & $-0.218^{*}$ & 0.120 & $-0.174 *$ & 0.095 & - & - & $-0.247^{*}$ & 0.133 \\
\hline Instrument count & 36 & - & 34 & - & 34 & - & 32 & - & 30 & - & 30 & - \\
\hline Observations & 309 & - & 318 & - & 341 & - & 309 & - & 318 & - & 341 & - \\
\hline Firm count & 48 & - & 49 & - & 49 & - & 48 & - & 49 & - & 49 & - \\
\hline AB-test for AR (1) & -3.66 & - & -3.77 & - & -3.69 & - & -3.66 & - & -3.79 & - & -3.69 & - \\
\hline Probability for AR (1) & 0.000 & - & 0.000 & - & 0.000 & - & 0.000 & - & 0.000 & - & 0.000 & - \\
\hline$A B$-test for $A R(2)$ & 0.92 & - & 0.65 & - & -0.82 & - & 0.93 & - & 0.63 & - & -0.83 & - \\
\hline Probability for AR (2) & 0.355 & - & 0.515 & - & 0.414 & - & 0.352 & - & 0.532 & - & 0.405 & - \\
\hline Probability H-test & 0.385 & - & 0.386 & - & 0.223 & - & 0.196 & - & 0.282 & - & 0.135 & - \\
\hline
\end{tabular}

Note: Windmeijer-corrected standard errors are in brackets. Firm count varies across models because firms with six or more negative values for tangible book value or earnings before interest and taxes from continuing operations are dropped automatically by the software for having too few observations.

$\mathrm{H}$-test, Hansen test; AB-test, Arellano-Bond test; MC, market capitalisation; TBV, tangible book value; EBITCO, earnings before interest and taxes from continuing operations; AR(k), autocorrelation of order $k$.

$* * *, 1 \%$ significance; $* *, 5 \%$ significance; *, $10 \%$ significance. 
The movements recorded for both the coefficient and the errors are small, implying that the results are robust to lag structure changes. The results show that EBITCO is useful in explicating firm value movements on the JSE.

Tangible book value also exhibits a positive relationship with $\mathrm{MC}$; as tangible book value increases, firm value also increases.

This is quite logical because an upsurge in TBV means that there is a rise in the residual value that is available to shareholders of the company in the event of liquidation. This gives a sense of security to investors. Firms with high TBV should, therefore, attract more investors, and this drives up the firms' MC. The coefficient of TBV is 0.144 in Model 7, which marginally changes to 0.146 in Model 10. Standard errors are small and they also change marginally between the two models. Nevertheless, the association between TBV and MC lacks statistical significance. This means that TBV is not useful in explaining firm value movements on the JSE.

Findings for Models 8 and 11: After dropping TBV and its first lag, the F-test reveals that the remaining explanatory variables still mutually explicate the movement in MC at $1 \%$ level. Model 8 makes use of 34 regression instruments whilst Model 11 uses 30 instruments. In either case, the instrument count is much lower than the 318 observations and 49 groups. Thus, no instrument proliferation exists.

Leaving out TBV causes the coefficient of EBITCO to move from a Model 7 value of 0.207 to 0.199 (Model 8). The association between MC and EBITCO is still positive and statistically significant ( $1 \%$ level).

Corrected standard errors also change marginally. These minor changes mean that the model is robust. Varying the lag limit triggers a marginal change in the coefficient of EBITCO from 0.199 (Model 8) to 0.200 (Model 11). Corrected standard errors are small, and they also register small changes, showing that the model is robust.

Findings for Models 9 and 12: Model 9 employs 34 instruments (both standard and GMM) as opposed to Model 12 , which employs 30 instruments. In either case, there are 341 observations. Comparing the instrument count and the total observations and number of groups shows that the problem of too many instruments is non-existent in the models.

As a result of omitting EBITCO from the model, the coefficient of TBV moves from 0.144 in Model 7 to 0.206 in Model 9. There is still a positive and insignificant association between MC and TBV. Omitting EBITCO thus has no effect on TBV's lack of value relevance. Varying the lag structure causes the coefficient of TBV to move from a Model 9 value of 0.206 to a Model 12 figure of 0.234 and the corrected standard errors change from 0.122 to 0.140 . The relationship remains insignificant at 5\% level. Varying lag limits has no effect on model results; Tangible book value is still not useful in explicating firm value movements. Diagnostic test results are discussed in the next section.

Diagnostic test results: Diagnostic test results are presented at the basement of Table 5. The Arellano-Bond test shows that, as expected, we reject the absence of first-order serial correlation in all the six models. However, we fail to reject the absence of second-order serial correlation in all the models because the $p$-values for AR (2) are all above $5 \%$. This testifies the non-existence of serial correlation in all the models. The Hansen test of over-identifying restrictions shows that the instruments used in these models are valid because all the probabilities for the Hansen test are above 5\%.

\section{Comparison of results for scenarios 1 and 2}

Results from Scenario 1 show a positive and statistically significant association between firm value (EV) and EBITCO across all the four models. Scenario 2 also shows a positive and statistically significant association between firm value (MC) and EBITCO across all the four models. Robustness checks implemented attest to the fact that all the models are robust. Diagnostic test results validate the models and authenticate their results.

This, therefore, shows that regardless of the measure of firm value used, EBITCO is value relevant. Earnings before interest and taxes from continuing operations explain movements in both $\mathrm{MC}$ and $\mathrm{EV}$.

The same two scenarios produce consistent results to the effect that TBV is devoid of value relevance. All eight models show that, at $5 \%$ significance level, TBV lacks value relevance. A discussion of these results follows.

\section{Discussion of findings}

The study's findings both confirm and dispute findings in extant literature. The relationship between EV and accounting variables is an issue that has not gained much attention from researchers. The enterprise value represents the takeover value or purchase price of a company. This study found that EBITCO is value relevant but TBV is not. This means that the takeover value of a firm is influenced by its EBITCO but not by its TBV.

Investors who wish to take over a firm can thus use that firm's EBITCO in their valuation models. The implication of EBITCO being value relevant where $\mathrm{EV}$ is the response variable is that if the firm is taken over, the new owners will get fair value for their money because what they pay (enterprise value) is directly related to the earnings of that company. This is one of the contributions of this study to value relevance research.

Earnings from continuing operations measure a firm's capacity to retain its going concern status and generate 
stockholder value consistently. This is important to investors after a takeover because investors are concerned about both the safety of their investments and a good return. Where a firm continues to grow its EBITCO, it means that besides the investors' funds being safe, a positive return will also be generated for the new owners.

Tangible book value does not necessarily determine future earnings, hence its lack of value relevance in this respect. What the new owners are interested in are future earnings to be generated by the firm that they would have taken over, and this is aptly represented by EBITCO. All in all, the findings in Scenario 1 support the hypothesis that firm value (EV) is influenced by EBITCO, but they also conflict with Hypothesis 2 which says that EV is related to TBV. The expectation was that EV will be influenced by TBV because the value of a firm in a takeover should be a reflection of what the firm's net assets are worth. Furthermore, it is the firm's assets that are used to generate earnings in the future. The higher the net assets, other things constant, the higher the potential to grow operating income in the future. Lack of value relevance probably means that intangible assets like goodwill and patents (disregarded in calculating tangible book value) are highly regarded when a firm is being valued for a takeover. This is a possibility considering the findings by Zulu et al. (2017) on the same market. However, more research is needed in this regard in order for a concrete affirmation of that hypothesis to be made. Another possible explanation on why TBV is not value relevant is that there are not many takeovers that occur on the JSE so the takeover value is not considered by many investors in their normal day-to-day trading. Takeover value will only be considered when there is news of such an event happening and the occurrence has been very rare. However, this argument is weakened by the statistical significance of the relationship between EV and the other variable, EBITCO.

Just like what was obtained in Scenario 1, the findings in Scenario 2 support the hypothesis that EBITCO influences MC (firm value), but TBV does not have an influence on MC. On the one hand, the results converge with Davern et al. (2019) who found out that EBIT and EBITDA possess information that helps explain the movement in equity prices in Australia. On the other hand, they also conflict with the same study regarding information content of book value. The current investigation established that TBV lacks value relevance, whilst Davern et al. (2019) say BV is value relevant. Similarly, this study's findings also partly dispute those by Dahmash and Qabajeh (2012) who used market capitalisation as a response variable in a modified Ohlson model by using Jordanian data. Specifically, they found that BV and abnormal earnings possess value relevance, with abnormal earnings having more explanatory power than BV. Their measure of earnings is different from the one used in this study, but the findings are in conformity with each other. The difference lies on BV, which they found to be value relevant whilst this research found that TBV lacks value relevance. Noteworthy, however, is the technical difference between the two measures (BV and TBV). Another possible explanation of the differences in findings is that the two studies focus on different markets. It does not mean that a variable has to be universally value relevant. Similarly, it does not mean that when a variable is not value relevant in one market, then, that has to be universal across different world markets. As dynamics in different markets are different, we should expect differences in what traders in one market consider when they trade relative to another market. However, one may argue that if the definition of value is the same, then, value drivers should not vary depending on the market being analysed.

Zulu et al. (2017) have found that BV of equity in interim financial statements is value relevant, but earnings lack value relevance on the JSE, contrary to this study where earnings are found to be value relevant whilst TBV is not. Use of interim financial statements and share prices recorded at year end versus those recorded after the third month from fiscal year end can help explain the difference in findings. Our findings corroborate what Omokhudu and Ibadin (2015) documented on the Nigerian equity market, where firm earnings proved to be value relevant but BV was not statistically significant.

A point to note regarding value relevance of earnings is the myriad versions of earnings used by researchers, and among them is net income after taxes before extraordinary items (Camodeca, Almici \& Brivio 2014), profit after tax (Khanna 2014) and comprehensive net income (Jahmani et al. 2017). The reason why some versions of earnings are not value relevant is that they do not provide useful information to investors with regard to a firm's ability to consistently churn a positive return in the future. For instance, comprehensive income includes income from discontinued operations and other non-core activities, which may not recur in the future. Furthermore, net income is affected by a firm's financing decision, such that given the same amount of EBIT for two firms, a highly geared firm's net income is much lower than that of a firm that has no debt because of debt interest payments. Whilst the tax-shield effect of debt has to be acknowledged for a levered firm, this is a financing issue rather than an operating issue. The difference in net income between the two firms does not mean that the levered firm performed poorly; it is simply a reflection of the firm's capital structure and that is not permanent. This research opines that value relevance lies more with persistent operating capacity (represented by operating income from continuing operations) rather than financing issues because future income is generated from sound operating decisions. This thread is also in line with Collins, Maydew and Weiss (1997:39) who argued that the decline in value relevance over the years is caused by '...the increasing frequency and magnitude of one-time items, the increasing frequency of negative earnings, and changes in average firm size and intangible intensity across time'.

\section{Recommendations}

The study revealed that EBITCO is value relevant. The calculation of this variable was made possible by the fact that companies in South Africa are mandated to produce 
comprehensive financial statements in line with International Financial Reporting Standards. Besides being value relevant, EBITCO provides more information about the going concern status of a company and the company's future cash flow levels.

This is very pertinent to various users of financial statement information. Therefore, accounting standards setters are advised to maintain the requirement that mandates companies to produce comprehensive financial statements. Earnings from discontinued operations have become more visible because of this requirement, thus making financial statements more informative about company operations. Companies' activities have become less opaque and such transparency helps to build resilient companies for the benefit of shareholders, management and workers, regulators and the macro-economy at large. Accounting standards setters can also put more measures that protect the integrity of reported EBITCO as a way of helping investors and ensuring that accounting statements remain useful to investors. Tangible book value is the other explanatory variable used, and it was found to lack value relevance. The calculation of the variable was possible because companies are mandated to disclose their intangible assets. Accounting standards setters can make the accounts more user friendly by including a clause that requires companies to have a line item called 'tangible book value' in their accounts.

Despite lack of value relevance, this measure provides a conservative view of a company's residual value, which is less susceptible to manipulation by preparers of financial statements.

Market capitalisation was used as one of the measures of firm value. It is a useful measure of firm value to stock market participants. Thus, accounting standards setters can make it mandatory for firms to report either share prices or market capitalisation recorded on the first trading day after announcement of a company's financial results. This information can be included in the annual report because the report is produced some months after announcement of results. This is not a weird suggestion because some companies already include their share prices in annual reports, but they only report share prices recorded on the last day of their fiscal year, and this is optional. Each company's fiscal year end is known from the financial statements, so share prices or market capitalisation as at the end of a company's fiscal year end can easily be ascertained. What is difficult to determine is market capitalisation on the day or just after the day the results were announced. Market capitalisation on the first trading day after announcement of results is useful to various users of financial statements such as investors, analysts and academic researchers in their various analyses of firms' stock market performance induced by announcement of results. This information is difficult to get because, when using archival data, one will never know the exact date when results were announced. Alternatively, this date has to be disclosed in the annual report. Disclosing this date can also be viewed as part of a company's evidence that they are complying with the mandatory requirement of producing financial results within 3 months of their fiscal year end.

Based on the findings that EBITCO is value relevant whilst TBV is not, investment analysts are advised to include EBITCO in their equity valuation models. This will enable the analysts to have better forecasts of future share prices. One of the scenarios showed that EBITCO explains enterprise value, which is a company's purchase price. Pursuant to this, investors who wish to take over a company are recommended to use EBITCO when they value a takeover target. Correlation analysis showed that market capitalisation and enterprise value are not very good proxies for each other because of their relationship whose strength is fairly average. Analysts and investors are, therefore, advised not to use these variables as proxies for each other. As an example, they should not use market capitalisation in a company takeover valuation. They should just stick to using enterprise value to avoid measurement error implied by a correlation coefficient that is far less than unity. A perfect positive correlation between variables implies that the variables can substitute for each other (perfect proxies). Whilst TBV conveys valuable information about a firm's realisable residual value upon liquidation, its inclusion in valuation models lacks substantial empirical backing. Executives of companies should put in place strategies that boost their EBITCO as a way of maximising shareholder value and increasing the value of their companies' shares. This will help them in case they want to do a rights issue, where they will fetch higher prices for the issued shares because the shares will be highly valued.

\section{Conclusion}

Based on the study's findings, we reject Hypothesis 1 but fail to reject Hypothesis 2. We thus conclude that EBITCO has a relationship with both enterprise value and market capitalisation whilst TBV does not explain both enterprise value and market capitalisation. These findings both confirm and conflict with the findings by other researchers. The study also concludes that, after a company's takeover, new owners are almost certain to derive value for their money because the enterprise value that they pay is linked to the company's earning capacity and the earnings are not transitory but are from continuing operations.

The novelty of this study centres on the methodology and how the explanatory variables were calculated.

Whilst extant literature invariably uses static models and OLS estimators, this study uses dynamic models and System GMM estimators. Regarding measurement of explanatory variables, the study adopted a conservative measure of book value of equity, that is, tangible book value. This is different from what most researchers have done. Furthermore, the study also focussed on operating income from continuing operations instead of the usual net income and abnormal earnings. 
The study's limitation is that it did not go further to find out the impact of accounting conservatism (embodied in how explanatory variables were measured) on the results of the study. Future studies can, therefore, determine whether or not the conservatism adopted in this study does indeed have an impact on the results. Also, further studies may include cash flows as another explanatory variable because of its widespread use in some valuation models.

\section{Acknowledgements}

The authors acknowledge useful comments and suggestions from the manuscript's anonymous reviewers.

\section{Competing interests}

The authors have declared that no competing interests exist.

\section{Authors' contributions}

A.S. conceived of the presented idea, developed the theory and performed the computations. O.P.A. and R.R. verified the analytical methods, computations and supervised the findings of this work. All authors discussed the results and contributed to the final manuscript.

\section{Ethical consideration}

This article followed all ethical standards for a research without direct contact with human or animal subjects.

\section{Funding information}

The research received no specific grant from any funding agency in the public, commercial or not-for-profit sectors.

\section{Data availability statement}

Data sharing is not applicable to this article as no new data were created or analysed in this study.

\section{Disclaimer}

The views and opinions expressed in this article are those of the authors and do not necessarily reflect the official policy or position of any affiliated agency of the authors.

\section{References}

Alexander, D., Falta, M. \& Willett, R., 2012, 'Using forecasting criteria to identify value relevance in the relationship between accounting numbers and market value', Abacus 48(3), 316-347. https://doi.org/10.1111/j.1467-6281.2012.00368.x

Baltariu, C.A., 2015, 'The current state of knowledge in the value relevance research field', SEA - Practical Application of Science III(I), 13-19.

Banz, R.W. \& Breen, W.J., 1986, 'Sample-dependent results using accounting and market data: Some evidence', The Journal of Finance 41(4), 779-793. https://doi. org/10.1111/j.1540-6261.1986.tb04548.x

Beisland, L.A., 2009, 'A review of the value relevance literature', The Open Business Journal 2, 7-27. https://doi.org/10.2174/1874915100902010007
Blundell, R. \& Bond, S., 1998, 'Initial conditions and moment restrictions in dynamic panel data models'. Journal of Econometrics 87, 115-143. https://doi. org/10.1016/S0304-4076(98)00009-8

Bond, S., 2002, Dynamic panel data models: A guide to micro data methods and practice, Working Paper 09/02, Institute for Fiscal Studies, London.

Camodeca, R., Almici, A. \& Brivio, A.R., 2014, 'The value relevance of accounting information in the Italian and UK stock markets', Problems and Perspectives in Management 12(4), 512-519.

Chandrapala, P., 2013, 'The value relevance of earnings and book value: The importance of ownership concentration and firm size', Journal of Competitiveness 5(2), 98-107. https://doi.org/10.7441/joc.2013.02.07

Clout, V.J. \& Willett, R., 2016, 'Analysing the market-book value relation in large Australian and US firms: Implications for fundamental analysis and the market-book ratio', Accounting and Finance 56, 1017-1040. https://doi.org/10.1111/acfi.12117

Collins, D., Maydew, E. \& Weiss, I., 1997, 'Changes in the value-relevance of earnings and book values over the past forty years', Journal of Accounting and Economics 1 , 39-67. https://doi.org/10.1016/S0165-4101(97)00015-3

Dahmash, F.N. \& Qabajeh, M., 2012, 'Value relevance of Ohlson model with Jordanian data', Interdisciplinary Journal of Contemporary Research in Business 3(11), 551-560.

Davern, M., Gyles, N., Hanlon, D. \& Pinnuck, M., 2019, 'Is financial reporting still useful? Australian evidence', Abacus 55(1), 237-272. https://doi.org/10.1111/ abac.12152

Der, B.A., Polak, P. \& Masri, M., 2016, 'Investigation on the value relevance of accounting information: Evidence from incorporated companies in the Singapore capital market', Investment Management and Financial Innovations 13(3), 9-21. https://doi.org/10.21511/imfi.13(3).2016.01

Glezakos, M., Mylonakis, J. \& Kafouros, C., 2012, 'The impact of accounting information on stock prices: Evidence from the Athens Stock Exchange', International Journal of Economics and Finance 4(2), 56-68. https://doi.org/10.5539/ijef.v4n2p56

Hai, T.T.T., Diem, N.N. \& Binh, H.Q., 2015, 'The relationship between accounting information reported in financial statements and stock returns - Empirical evidence from Vietnam', International Journal of Accounting and Financial Reporting 5(1), 229-238. https://doi.org/10.5296/ijafr.v5i1.7473

Jahmani, Y., Choi, H.Y., Park, Y. \& Wu, G.J., 2017, 'The value relevance of other comprehensive income and its components', Accounting and Taxation 9(1), 1-11.

Khanna, M., 2014, 'Value relevance of accounting information: An empirical study of selected of selected indian firms', International Journal of Scientific and Research Publications 4(10), 364-369.

Lev, B. \& Gu, F., 2016, The end of accounting and the path forward for investors and managers, John Wiley \& Sons Inc., New Jersey.

Mirza, A., Malik, M. \& Abdul-Hamid, M.A., 2018, 'Value relevance of earnings and book value of equity: Evidence from Malaysia', Global Business Management Review 10(2), 19-40.

Nyabundi, M.A., 2013, 'Value relevance of financial statements information: Evidence from listed firms in Kenya', Advances in Management and Applied Economics 3(1), 115-134.

Ohlson, J.A., 1995, 'Earnings, book values, and dividends in equity valuation', Contemporary Accounting Research 11(2), 661-687. https://doi.org/10.1111/ j.1911-3846.1995.tb00461.x

Olugbenga, A.A. \& Atanda, O.A., 2014, 'The relationship between financial accounting information and market values of quoted firms in Nigeria', Global Journal of Contemporary Research in Accounting, Auditing and Business Ethics 1(1), 22-39.

Omokhudu, O.O. \& Ibadin, P.O., 2015; 'The value relevance of accounting information: Evidence from Nigeria', Accounting and Finance Research 4(3), 20-30. https://doi. org/10.5430/afr.v4n3p20

Pavone, P., 2019, 'Market capitalization and financial variables: Evidence from Italian listed companies', International Journal of Academic Research in Business and Social Sciences 9(3), 1356-1371. https://doi.org/10.6007/IJARBSS/v9-i3/5802

Pervan, I. \& Bartulovic, M., 2014, 'Value relevance of accounting information: Evidence from South Eastern European countries', Economic Research-Ekonomska Istrazivanja 27(1), 181-190. https://doi.org/10.1080/1331677X.2014.947132

Roodman, D., 2009, "How to do xtabond2: An introduction to "Difference" and "System" GMM in Stata', Stata Journal 9(1), 86-136. https://doi.org/ 10.1177/1536867X0900900106

Sixpence, A. \& Adeyeye, O.P., 2019, 'Value relevance of book values and earnings of listed non-financial firms in South Africa: A dynamic panel analysis', International Journal of Monetary Economics and Finance 12(4), 290-308. https://doi. org/10.1504/IJMEF.2019.10021936

Sixpence, A., Adeyeye, O.P. \& Rajaram, R., 2020, 'Impact of relative and absolute financial risks on share prices: A Zimbabwe Stock Exchange perspective', Investment Management and Financial Innovations 17(1), 1-14. https://doi. org/10.21511/imfi.17(1).2020.01

Zulu, M., De Klerk, M. \& Oberholster, J.G.I., 2017, 'A comparison of the value relevance of interim and annual financial statements', South African Journal of Economic and Management Sciences 20(1), 1-11. https://doi.org/10.4102/ sajems.v20i1.1498 